\title{
ISOLATED TRAUMATIC DISLOCATION OF THE RADIAL HEAD IN CHILDREN
}

\author{
D. A. HUDSON. J. DE V. DE BEER
}

From the Red Cross Children's Hospital, Cape Town

\begin{abstract}
Isolated traumatic dislocation of the radial head in children is not as rare as sometimes supposed. Attention to detail in radiographic interpretation is the key to diagnosis. Early closed reduction and immobilisation in an above-elbow plaster in 90 of flexion and full supination for three to six weeks is recommended. Seven cases are presented, two of which were treated operatively and had unsatisfactory results. The applied anatomy, management and complications are discussed.
\end{abstract}

Isolated traumatic dislocation of the radial head in children has been described in the literature as "an extremely rare injury" (Hamilton and Parkes 1973). Seven patients with this injury were seen at the Red Cross Children's Hospital, Cape Town, between January 1984 and June 1985 (Table I). Instances of "pulled elbow" and patients with associated fractures of the radius or ulna were excluded. No patients with features suggestive of congenital radial head dislocation were encountered. The pathophysiology. problems, management and complications are discussed, together with a review of the literature.

\section{FINDINGS}

Incidence. A review of the English language literature revealed a total of 46 reported cases; the largest single series of 12 (Stelling and Cote 1956) was seen over a period of 20 years. They found that isolated traumatic radial head dislocation in children occurred mainly between the age of two and seven years, with no sex or ethnic predominance. The criteria for congenital dislocation, defined by McFarland (1936) and Mardam-Bey and Ger (1979) are shown in Table II, but were not seen in our cases.

Congenital dislocation of the radial head is a welldescribed entity (Gunn and Pillay 1964: Almquist, Gordon and Blue 1969). However, when the dislocation is unilateral, a congenital aetiology has been questioned

D. A. Hudson. MB ChB. Registrar

Trauma Unit. Department of Surgery. Red Cross Children's Hospital. Rondebosch 7700. Cape Town. South Africa.

J. De V. De Beer, MB ChB. Registrar

co Department of Orthopaedic Surgery. University of Cape Town. Observatory 7700, Cape Town. South Africa.

Requests for reprints to be sent to Dr J. De V. De Beer.

1. 1986 British Editorial Society of Bone and Joint Surgery $0301620 \times 863091 \$ 2.00$ by many, because missed traumatic dislocation appears more likely. In addition, as isolated traumatic radial head dislocation has been reported in a neonate after difficult breech delivery (Schubert 1965), the discovery of dislocation in the neonatal period does not necessarily preclude a traumatic origin. A further difficulty in determining the aetiology is that a chronically dislocated radial head, even if traumatic, will subsequently develop radiological changes similar to those of congenital dislocation (Lloyd-Roberts and Bucknill 1977). Stelling and Cote (1956), in their review of isolated traumatic radial head dislocations, stated that "it is our feeling that a significant number of these cases remain undiagnosed, or are loosely ascribed to the group of congenital dislocation and that, for this reason alone, the true incidence of this condition is underestimated". This paper supports these views.

Applied anatomy. The normal anatomy has been extensively reviewed by Wiley, Pegington and Horwich (1974). They found the annular ligament to be the most crucial factor in maintaining the stability of the radial head. Complete dislocation of the radial head cannot occur without complete disruption of this ligament. Lesser supporting structures include the interosseous membrane (taut in supination and neutral rotation); the quadrate ligament (anterior fibres taut in supination, posterior fibres taut in pronation), and the oblique cord (taut in supination). These are shown in Figure 1.

Three types of dislocation have been described, posterior, lateral and anterior. Anterior dislocation occurs more commonly and was the only variety encountered in our series.

Mechanism of injury. Two possible mechanisms have been proposed: a hyperpronation force applied to the (partly) extended elbow with or without additional varus strain (Evans 1949; Vesely 1967); or a hyperextension force applied to the fully supinated forearm with or without the superimposed pull of the biceps (Smith 1972). 
Table I. Details of 7 patients all of whom had anterior dislocation of the radial head

\begin{tabular}{|c|c|c|c|c|c|c|c|c|}
\hline Case & $\begin{array}{l}\text { Age } \\
\text { (years) }\end{array}$ & Sex & History & Examination & Management & Immobilisation & $\begin{array}{l}\text { Follow-up } \\
\text { period }\end{array}$ & Final result \\
\hline 1 & 6 & $\mathrm{~F}$ & $\begin{array}{l}\text { Fell } 4 \text { days before } \\
\text { presentation. } \\
\text { injuring } \mathrm{L} \text { arm }\end{array}$ & $\begin{array}{l}\text { Tender, swollen } \\
\text { elbow; decreased } \\
\text { range of all } \\
\text { movements }\end{array}$ & Closed reduction & $\begin{array}{l}\text { Collar and cuff for } 4 \\
\text { weeks }\end{array}$ & 1 year & $\begin{array}{l}\text { Full range of } \\
\text { movement }\end{array}$ \\
\hline 2 & 7 & $\mathrm{~F}$ & $\begin{array}{l}\text { Direct blow to L } \\
\text { elbow }\end{array}$ & $\begin{array}{l}\text { Tender, swollen } \\
\text { elbow; decreased } \\
\text { range of all } \\
\text { movements }\end{array}$ & Closed reduction & $\begin{array}{l}\text { Plaster cast--90 } \\
\text { flexion, full } \\
\text { supination; collar } \\
\text { and cuff for } 4 \text { weeks }\end{array}$ & 3 months & $\begin{array}{l}\text { Full range of } \\
\text { movement }\end{array}$ \\
\hline 3 & 1 & M & $\begin{array}{l}\text { Fell injuring } \mathrm{L} \\
\text { elbow }\end{array}$ & $\begin{array}{l}\text { Tender, swollen } \\
\text { elbow; decreased } \\
\text { range of all } \\
\text { movements }\end{array}$ & Closed reduction & $\begin{array}{l}\text { Plaster cast-90 } \\
\text { flexion, full } \\
\text { supination; collar } \\
\text { and cuff for } 4 \text { weeks }\end{array}$ & 4 weeks & $\begin{array}{l}\text { Full range of } \\
\text { movements }\end{array}$ \\
\hline 4 & 5 & $\mathrm{~F}$ & $\begin{array}{l}\text { Fell } 6 \text { weeks before } \\
\text { presentation, } \\
\text { injuring } R \text { elbow }\end{array}$ & $\begin{array}{lrl}\text { Flexion: } & 45 & 120 \\
\text { Pronation: } & 0 & -45 \\
\text { Supination: } & 0 & \end{array}$ & $\begin{array}{l}\text { Open reduction; } \\
\text { reefing of annular } \\
\text { ligament; K-wire } \\
\text { fixation }\end{array}$ & $\begin{array}{l}\text { Plaster backslab- } \\
90 \text { flexion, full } \\
\text { supination; collar } \\
\text { and cuff for } 3 \text { weeks; } \\
\text { then K-wire } \\
\text { removed }\end{array}$ & 1 year & $\begin{array}{l}\text { Radial head } \\
\text { redisplaced } \\
\text { Flexion: Nearly full } \\
\text { Extension: Full } \\
\text { Supination: Full } \\
\text { Pronation: } 0-45\end{array}$ \\
\hline 5 & 8 & $\mathrm{M}$ & $\begin{array}{l}\text { Fell } 6 \text { weeks before } \\
\text { diagnosis: initially } \\
\text { treated as soft- } \\
\text { tissue injury }\end{array}$ & $\begin{array}{l}\text { Tender, swollen } \\
\text { L elbow; decreased } \\
\text { range of all } \\
\text { movements }\end{array}$ & $\begin{array}{l}\text { Open reduction; } \\
\text { Bell-Tawse } \\
\text { procedure; K-wire } \\
\text { fixation }\end{array}$ & $\begin{array}{l}\text { Plaster cast-90 } \\
\text { flexion, full } \\
\text { supination; collar } \\
\text { and cuff for } 3 \text { weeks; } \\
\text { then K-wire } \\
\text { removed }\end{array}$ & 6 months & $\begin{array}{lrr}\text { Flexion: } \quad 40 & 135 \\
\text { Supination: } & 0 & \\
\text { Pronation: } & 0 & -15\end{array}$ \\
\hline 6 & 8 & M & Fell onto L arm & $\begin{array}{l}\text { Tender, swollen } \\
\text { elbow; decreased } \\
\text { range of all } \\
\text { movements }\end{array}$ & Closed reduction & $\begin{array}{l}\text { Plaster cast-90 } \\
\text { flexion, full } \\
\text { supination; collar } \\
\text { and cuff for } 3 \text { weeks }\end{array}$ & 2 months & $\begin{array}{l}\text { Full range of } \\
\text { movement }\end{array}$ \\
\hline 7 & 5 & $\mathbf{F}$ & $\begin{array}{l}\text { Pedestrian in road } \\
\text { accident, multiple } \\
\text { injuries }\end{array}$ & $\begin{array}{l}\text { Tender, swollen } \\
\text { L elbow; palpable } \\
\text { anterior dislocation of } \\
\text { radial head }\end{array}$ & Closed reduction & $\begin{array}{l}\text { Plaster cast-90 } \\
\text { flexion, neutral } \\
\text { rotation; collar and } \\
\text { cuff for } 4 \text { weeks }\end{array}$ & 2 months & $\begin{array}{l}\text { Full range of } \\
\text { movements }\end{array}$ \\
\hline
\end{tabular}

Table II. Criteria for diagnosing congenital dislocation

McFarland 1936

1. Relatively short ulna/long radius

2. Hypoplastic/absent capitulum

3. Partially defective trochlea

4. Prominent ulnar epicondyle

5. Dome-shaped radial head with a long narrow neck

6. Grooving of the distal radius

Mardam-Be' and Ger 1979

1. Bilateral involvement

2. Concurrence of other congenital anomalies

3. Familial occurrence

4. No history of trauma

5. Irreducibility by closed methods

6. Dislocation seen at birth

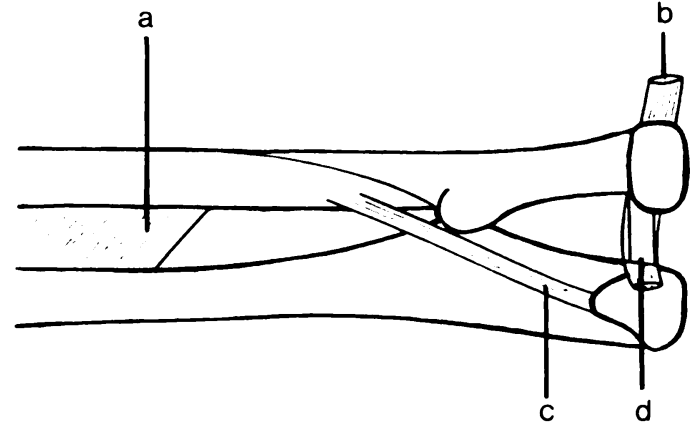

Fig. 1

Diagram of the interconnections between the radius and ulna: $a$, interosseous membrane: $b$, annular ligament: $c$, oblique cord: and $d$, quadrate ligament. 


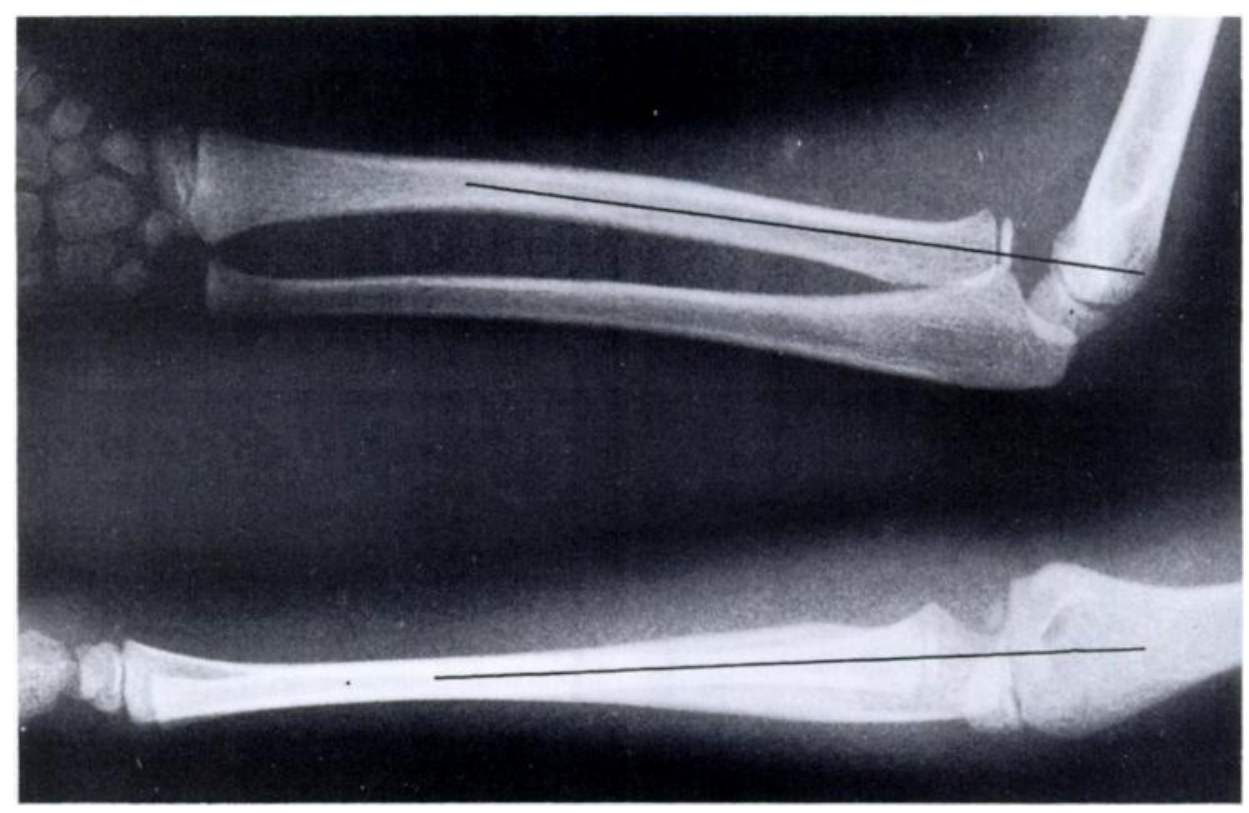

Fig. 2

A seven-sear-old girl in whom the diagnosis of dislocation is confirmed by the fact that a line drawn through the mid-shaft of the radius misses the capitulum.

However, in our series it has been impossible to establish a mechanism of injury in all instances, and this experience coincides with that of other authors.

Diagnosis. The child usually presents with a painful swollen elbow. Passive movement may be surprisingly free in flexion and extension. but is limited in pronation and especially supination. However, in the acute stage, associated pain usually restricts all movements at both the elbow and radio-ulnar joints. The injury can result from surprisingly minor trauma (Lloyd-Roberts and Bucknill 1977). and therefore a high index of suspicion is imperative. together with careful assessment of the radiographic findings. Both anteroposterior and lateral views of the elbow are required. On the lateral view, a line drawn through the long axis of the radial shaft should always pass through the centre of the capitulum. irrespective of the degree of flexion of the elbow (Storen 1958). The radiological findings are conclusive in the diagnosis of this condition (Fig. 2).

Management. Whether the management should be conservative or operative depends on the ease of reduction and of maintenance, as well as the delay before management starts. In the acute case, reduction may be effected by traction and full supination with the application of direct pressure over the radial head (Wiley et al. 1974). The elbow is usually immobilised in an above-elbow plaster cylinder with the elbow flexed 90 and the forearm in full supination (Vesely 1967: Hamilton and Parkes 1973: Zivkovic 1978). This position adds to the stability of reduction by diminishing the pull of the biceps and tensing both the interosseous membrane (Wiley et al. 1974) and the anterior fibres of the quadrate ligament (Spinner and Kaplan 1970). In addition, maintenance of reduction may be supplemented by a percuta- neous trans-capitular Kirschner wire which, however. has not been proved necessary in this series.

The duration of immobilisation varies from three to six weeks (Hume 1957: Vesely 1967: Hamilton and Parkes 1973), being three to four weeks in our series. Five of our acute dislocations were easily reduced by closed means. However, an instance of acute irreducibility necessitating open reduction has been reported by Neviaser and LeFevre (1971) who described an irreducible button-holing of the radial head through a transverse tear in the annular ligament. Management of the patient whose diagnosis has been excessively delayed (by three weeks or more) is controversial. Recommendations include open reduction, with or without repair or reconstruction of the annular ligament (Vesely 1967; LloydRoberts and Bucknill 1977), as well as non-intervention with possible delayed excision of the radial head, should this prove necessary once maturity has been reached (Stelling and Cote 1956)

Complications. In this series, no myositis ossificans or neurovascular complications were encountered. However, myositis ossificans is described in the literature, especially if reduction is delayed or after operative intervention. One patient (Case 4. Table I) redisplaced, but it has been shown that this may cause surprisingly little disability (Vesely 1967).

\section{DISCUSSION}

Isolated traumatic dislocation of the radial head has been regarded by many as a "para-Monteggia" lesion (Živković 1978). The absence of a concomitant ulnar fracture is at least in part due to the plasticity of the ulna in children. This permits transient bowing of the bone 
without it fracturing: up to 45 of bending may occur before a greenstick fracture results (Handelsman 1983). However. as in the case reported by Živković, follow-up radiographic examination in our series failed to demonstrate evidence of either periosteal reaction or bowing of the ulna. This negative finding raises the possibility that weakness of the annular ligament predisposes to rupture, with consequent radial head dislocation even without significant ulnar trauma. While the Monteggia lesion undoubtedly occurs more frequently, it appears that an isolated dislocation of the radial head is not as rare as has been previously thought. The diagnosis may easily be missed because the history is often vague, the clinical findings inconclusive, and the radiological features relatively subtle. Careful radiological examination is the key to the diagnosis.

The small numbers of this series precludes our proposing a definitive protocol regarding management. However, after early diagnosis, closed manipulation together with immobilisation in an above-elbow plaster in 90 of flexion and full supination for three to six weeks proved satisfactory in five patients; two patients treated operatively had unsatisfactory results.

We wish to thank Dr R. B. Goldschmidt. Dr J. Gordon and Dr M. Singer for their kind assistance and guidance in the preparation of this paper.

\section{REFERENCES}

Almquist EE, Gordon LH, Blue Al. Congenital dislocation of the head of the radius. J Bome Joint Surg $[A m]$ 1969:51-A:1118 27.

Evans EM. Pronation injuries of the forearm: with special reference to the anterior Monteggia fracture. J Bone Joint Surg [Br] 1949;31-B: 578-88.

Gunn DR. Pillay VK. Congenital posterior dislocation of the head of the radius. Clin Orthop 1964:34:108 13.

Handelsman JR. Management of fractures in children. Surg Clin North Am 1983:63:629-70.

Hamilton W, Parkes JC II. Isolated dislocation of the radial head without fracture of the ulna. Clin Orthop 1973:97:94-6.

Hume AC. Anterior dislocation of the head of the radius associated with undisplaced fracture of the olecranon in children. J Bone Joint Surg $[\mathrm{Br}]$ 1957:39 B: $508-12$.

Lloyd-Roberts GC, Bucknill TM. Anterior dislocation of the radial head in children: aetiology, natural history and management. J Bone Joint Surg $[B r]$ 1977:59 B:402 7 .

Mardam-Bey T, Ger E. Congenital radial head dislocation. $J$ Hand Surg 1979:4:316 20.

McFarland B. Congenital dislocation of head of radius. Br J Surg 1936: 24:41-9.
Neviaser RJ, LeFevre GW. Irreducible isolated dislocation of the radial head: a case report. Clin Orthop 1971:80:72 4.

Schubert JJ. Dislocation of the radial head in the newborn infant: case report and review of the literature. J Bome Joint Surg $[A m] 1965$; 47-A: $1019-23$.

Smith FM. Surgery of the elhow: 2nd ed. Philadelphia etc: WB Saunders, 1972.

Spinner M, Kaplan EB. The quadrate ligament of the elbow: its relationship to the stability of the proximal radio-ulnar joint. Acta Orthop Scand 1970:41:632 47.

Stelling FH, Cote RH. Traumatic dislocation of head of radius in children. JAMA 1956:160:732 6.

Steren G. Traumatic dislocation of the radial head as an isolated lesion in children: report of one case with special regard to roentgen diagnosis. Acra Chir Scand 1958:116:1447.

Vesely DG. Isolated traumatic dislocations of the radial head in children. Clin Orthop 1967:50:31 6.

Wiley JJ, Pegington J, Horwich JP. Traumatic dislocation of the radius at the elbow. J Bone Joint Surg [Br] 1974:56 B:501 7.

Zivkovic S. Traumatic dislocation of the radial head in a 5-year-old boy: case report. J Trauma 1978:18:289 90. 